\title{
TINGKAT STRES DAN PERAWATAN DIRI (SELF CARE) PADA KLIEN DIABETES MELITUS TIPE 2 DI POLI PENYAKIT DALAM BLUD RSUD dr. DORIS SYLVANUS
}

\author{
Level Of Stress And Self-Care Care In Clients Of Diabetes Melitus Type 2 In Poly \\ Disease In Blud RSUD dr. Doris Sylvanus
}

\author{
Natalansyah ${ }^{\text {** }}$ \\ Wulandari ${ }^{2}$ \\ H. Barto Mansyah ${ }^{3}$ \\ *IPalangka Raya, Kalimantan \\ Tengah, Indonesia \\ 2Palangka Raya, Kalimantan \\ Tengah, Indonesia \\ 3Palangka Raya, Kalimantan \\ Tengah, Indonesia \\ *email: \\ natalansyah@yahoo.co.id.
}

\section{Kata Kunci:}

Diabetes Melitus

Stress

Perawatan Diri

Keywords:

Diabetes Mellitus

Stress

Self Care

\begin{abstract}
Abstrak
International Diabetes Federation (IDF) memperkirakan adanya kenaikan jumlah penyandang DM di Indonesia dari 9, I Juta pada tahun 2014 menjadi I4,I Juta pada tahun 2035. DM tipe 2 adalah jenis yang paling umum terjadi. Diabetes adalah kelompok penyakit metabolik yang ditandai dengan hiperglikemia akibat defek sekresi insulin, aksi insulin, atau keduanya. Diabetes Melitus dapat menimbulkan berbagai perubahan atau gangguan fisik maupun psikologis bagi klien dimana mereka harus tergantung pada terapi pengelolaan diabetes. Tujuan dari penelitian ini adalah untuk mengetahui hubungan tingkat stres dengan perawatan diri (self care) pada klien DM tipe 2 di Poli Penyakit Dalam BLUD RSUD dr. Doris Sylvanus. Metoda penelitian ini menggunakan rancangan penelitian cross sectional, dengan teknik pengambilan sampel purposive sampling, jumlah sampel pada penelitian ini adalah 35 responden, pengumpulan data menggunakan kuesioner The Summary of Diabetes Self-Care Activities (SDSCA dan Diabetes Distress Scale (DSS) dan di analisis menggunakan uji chi square. Hasil penelitian ini menunjukkan bahwa dari 20 responden yang stres berat 18 responden kurang baik dalam melakukan perawatan diri dan dari 15 responden yang mengalami stres ringan 10 responden dapat melakukan perawatan diri dengan baik. Pada hasil uji chi square di dapatkan nilai $p$ value $=0,00$ I, dimana nilai $p<\alpha(\alpha=0,05)$. Dapat disimpulkan bahwa terdapat hubungan yang signifikan antara tingkat stres dengan perawatan diri dimana semakin tinggi tingkat stres maka semakin rendah perilaku perawatan dirinya.
\end{abstract}

\begin{abstract}
The International Diabetes Federation (IDF) estimates the number of DM increases in Indonesia from 9.1 million in 2014 to 14.1 million in 2035. Type 2 diabetes is the most common type. Diabetes is a group of metabolic diseases characterized by hyperglycemia due to defects in insulin secretion, insulin action, or a combination. Diabetes mellitus can cause clinical changes in diabetics.

The purpose of this study was to study the relationship of stress levels with self-care (self-care) on type 2 DM clients in BLUD Internal Medicine dr. Doris Sylvanus. This research method uses a cross sectional study design, with a purposive sampling technique, the number of samples in this study were 35 respondents, collecting data using a Diabetes Self-Care Activity Summary questionnaire (SDSCA and Diabetes Disorders Scale (DSS) and analyzed using the chi square test The results of this study indicate that of the 20 respondents who were severely stressed 18 respondents were not good in self-care and of the 15 respondents who increased mild stress 10 respondents were able to perform self-care well. $=0.00$ I, where the $p$ value $<\alpha(\alpha$ $=0$ 05) It can be concluded that there is a significant relationship between stress levels and self-care where the higher the stress level, the lower the self-care treatment.
\end{abstract}

C) year The Authors. Published by Institute for Research and Community Services Universitas Muhammadiyah Palangkaraya. This is Open Access article under the CC-BY-SA License (http://creativecommons.org/licenses/by-sa/4.0/). DOI: https://doi.org// 0.33084/jsm.vxix.xxx.

\section{PENDAHULUAN}

Menurut World Health Organization (WHO) kematian akibat Penyakit Tidak Menular (PTM) diperkirakan akan terus meningkat di seluruh dunia, peningkatan terbesar akan terjadi di negara-negara menengah dan miskin. Lebih dari dua pertiga (70\%) dari populasi global akan meninggal akibat penyakit tidak menular. Salah satu penyakit tidak menular adalah diabetes melitus (DM). DM merupakan penyakit gangguan metabolik menahun akibat pankreas tidak memproduksi cukup insulin atau tubuh tidak dapat menggunakan insulin yang diproduksi secara efektif (Pusat Data Dan Informasi Kementerian Kesehatan RI, 20I4). 
WHO memperkirakan bahwa secara global, 422 juta orang dewasa yang berusia $>18$ tahun hidup dengan diabetes. Jumlah penderita diabetes telah meningkat dalam dekade terakhir, karena populasi pertumbuhan peningkatan usia, dan kenaikan prevalensi diabetes setiap umur (WHO, 2016). International Diabetes Federation (IDF) memperkirakan adanya kenaikan jumlah penyandang DM di Indonesia dari 9,I Juta pada tahun 2014 menjadi I4,I Juta pada tahun 2035. DM tipe 2 adalah jenis yang paling umum terjadi, dan telah meningkat bersama budaya dan perubahan sosial, sekitar $90 \%$ dari semua kasus diabetes adalah tipe 2 (IDF Atlas, 2017).

Pada tahun 2015, Indonesia menempati peringkat ke tujuh di dunia untuk prevalensi penderita diabetes tertinggi di dunia bersama dengan China, India, Amerika Serikat, Brazil, Rusia dan meksiko dengan jumlah estimasi orang dengan diabetes sebesar 10 Juta (IDF Atlas, 2017). Prevalensi orang dengan diabetes di Indonesia menunjukan peningkatan yaitu dari tahun 2007 sebesar 5,7\% menjadi 6,9\% pada tahun 2013 (Riskesdas, 2018).

Kasus Diabetes Melitus merupakan salah satu penyakit terbanyak di Provinsi Kalimantan Tengah dan cenderung mengalami peningkatan dari tahun 2015 yaitu dengan jumlah kasus 5.137 menjadi 7.254 pada tahun 2016. Di Instalasi Rawat Jalan BLUD RSUD dr. Doris Sylvanus DM juga merupakan salah satu penyakit terbanyak dengan jumlah 4.108 kasus pada tahun 2016 (Badan Pusat Statistik Kalimantan Tengah, 2016).

Berdasarkan catatan rekam medik BLUD RSUD dr. Doris Sylvanus kasus diabetes melitus tak tergantung insulin di Instalasi Rawat jalan Poli Penyakit Dalam tahun 2017 sebanyak 4.942 kasus dimana jumlah penderita perempuan 2.759 lebih banyak dari pada lakilaki 2.l83 ( BPS Kalteng, 2017).

Diabetes Melitus dapat menimbulkan berbagai perubahan atau gangguan fisik maupun psikologis bagi klien dimana mereka harus tergantung pada terapi pengelolaan diabetes. Keharusan pasien diabetes melitus mengubah pola hidupnya agar gula darah dalam tubuh tetap seimbang dapat mengakibatkan mereka rentan terkena stres, karena stres akan terjadi apabila seseorang merasakan adanya ketidaksesuaian antara sumber daya yang dimiliki dengan tuntutan situasi yang harusdijalankan, ketika tuntutan situasi dirasakan berbeda dengan situasi sebelumnya dan terlalu berat maka stres akan terjadi. Stres merupakan gangguan pada tubuh dan pikiran yang disebabkan oleh tuntutan kehidupan. Abolghasemi dan Mahmoudi (2012) menyatakan permasalahan psikologis yang dialami orang-orang yang menderita DM 99\%, antara lain adalah stres. Begitu pula penelitian Hurai dalam Nurrokmah (2014) menyatakan bahwa pasien diabetes melitus umumnya menderita stres. Penelitian serupa juga dilakukan oleh Rehman dalam Loriza SY (2017) terhadap 240 pasien DM tipe 2 didapatkan yang mengalami stres $69,2 \%$.

Elpriska (2016) menyatakan pada keadaan stres akan terjadi peningkatan hormonkatekolamin, glukagon, glukokortikoid, Bendrotopin dan hormon pertumbuhan. Selanjutnya kortisol juga akan berdampak terhadap penurunan daya tahan tubuh penderita DM tipe 2, sehingga akan mudah untuk mengalami permasalahan kesehatan. Dampak yang terjadi baik fisik maupun psikologis tentunya akan berlanjut terhadap penurunan kemampuan dalam melakukan perawatan diri sendiri. Stres berhubungan dengan penurunan kemampuan individu dalam melakukan perawatan dirinya. Klien yang mengalami stres, memiliki motivasi dan manajemen diri yang rendah sehingga kemampuan dalam mengontrol gula darah kurang.

Hasil Penelitian Helme dan Legman dalam Gillani (20/2) menyebutkan bahwa hanya sekitar 7- $25 \%$ penyandang DM patuh terhadap semua aspek perilaku perawatan diri. Sekitar 40-60\% mengalami kegagalan diet, 30-80\% tidak patuh terhadap kontrol gula darah dan $70-80 \%$ tidak patuh terhadap olahraga. Penelitian Kusniawati (20I I) mendapatan bahwa rata-rata pasien dengan DM melakukan perawatan diri diabetes adalah 4,9 hari dalam seminggu, penelitian ini menunjukan bahwa klien DM belum melaksanakan perawatan diri secara penuh 7 hari dalam seminggu.

Hasil Penelitian yang dilakukan oleh Aliaputri (2014) di RSUD Raden Mattaher menyatakan bahwa Sumber stress berasal dari diri pasien sendiri bahwa mereka kewalahan dengan peraturan manajemen DM.

Berdasarkan uraian diatas membuat peneliti tertarik melakukan penelitian mengenai Hubungan Tingkat Stres dengan Perawatan diri (selfcare).

\section{METODOLOGI}

Penelitian ini adalah penelitian yang bersifat korelasi dengan menggunakan rancangan penelitian cross sectional. Populasi dalam penelitian ini adalah klien Diabetes tipe 2 yang Rawat jalan di Poli Penyakit Dalam BLUD RSUD dr. Doris Sylvanus pada bulan Desember tahun 2017 sebanyak 392 jiwa. Jumlah sampel pada penelitian ini ditentukan menggunakan rumus beda proporsi 
dandidapatkan sampel pada penelitian ini adalah 35 orang responden. Pengambilan sampel dalam penelitian ini menggunakan tehnik purposive sampling (sampel bertujuan) dengan cara menentukan sampel dengan pertimbang tertentu yang sesuai dengan kriteria yang ditetapkan oleh peneliti. Pada penelitian ini instrumen yang digunakan adalah kuesioner The Summary of Diabetes Self-Care Activities (SDSCA dan Diabetes Distress Scale (DSS).

Pelaksanaan pengumpulan data yang dilakukan dengan mengidentifikasi klien DM tipe 2 yang sesuai dengan kriteria inklusi; Memperkenalkan diri dan kontrak waktu dengan klien; Menjelaskan maksud dan tujuan penelitian kepada responden; Responden yang bersedia untuk dijadikan responden penelitian diminta untuk mengisi informed consent; Responden diminta untuk mengisi kuesioner Distres diabetes scale terlebih dahulu kemudian dilanjutkan mengisi kuesioner perawatan diri diabetes; Semua kuesioner yang telah diisi oleh responden dikumpulkan kembali.

\section{HASIL DAN PEMBAHASAN}

\section{Karakteristik Responden}

Tabel I. Karakteristik Responden Diabetes Melitus, di Poli Penyakit Dalam BLUD RSUD dr. Doris Sylvanus tahun 2018.

\begin{tabular}{|c|c|c|}
\hline Variabel & $\mathbf{F}$ & $\%$ \\
\hline \multicolumn{3}{|l|}{ Jenis Kelamin } \\
\hline Laki-laki & 14 & 40 \\
\hline Perempuan & 21 & 60 \\
\hline Jumlah & 35 & 100 \\
\hline \multicolumn{3}{|l|}{ Usia } \\
\hline $35-45$ Tahun & 13 & 37,1 \\
\hline$>45$ Tahun & 22 & 62,9 \\
\hline Jumlah & 35 & 100 \\
\hline \multicolumn{3}{|l|}{ Tingkat Pendidikan } \\
\hline SMP & 3 & 8,6 \\
\hline SMA & 18 & 51,4 \\
\hline Perguruan Tinggi & 14 & 40 \\
\hline Jumlah & 35 & 100 \\
\hline \multicolumn{3}{|l|}{ Pekerjaan } \\
\hline Tidak Bekerja & 17 & 48,6 \\
\hline Wiraswasta & 10 & 28,6 \\
\hline PNS & 8 & 22,9 \\
\hline Jumlah & 35 & 100 \\
\hline \multicolumn{3}{|l|}{ Lama DM } \\
\hline I-5 Tahun & 21 & 60 \\
\hline$>5$ Tahun & 14 & 40 \\
\hline Jumlah & 35 & 100 \\
\hline
\end{tabular}

Berdasarkan table I menunjukan bahwa jumlah responden $(n=35)$. PNS 22,9\%. Mayoritas responden telah terdiagnosa DM I-5 tahun yaitu $60 \%$, dan $40 \%$ terdiagnosa > 5 tahun. Pada penelitian ini responden lebih banyak mengalami stres berat yaitu $57,1 \%$ dibandingkan stres ringan sebanyak $42,9 \%$. Sebanyak $34,3 \%$ responden dapat melakukan perawatan diri dengan baik dan 65\% responden kurang baik dalam melakukan perawatan diri. Dari 35 responden di Poli Penyakit dalam BLUD RSUD dr. Doris didapatkan hasil perempuan lebih banyak menderita DM yaitu $60 \%$ dibandingkan laki-laki $40 \%$. Berdasarkan usia terdapat 13 responden dengan persentase $37,1 \%$ berusia $35-45$ tahun dan 22 responden berusia $>45$ tahun dengan presentase 62,9\%. Berdasarkan tingkat pendidikan didapatkan hasil 8,6\% responden berpendidikan SMP, 5I,4\% responden berpendidikan SMA dan $40 \%$ responden berpendidikan perguruan tinggi. Berdasarkan pekerjaan responden lebih banyak tidak bekerja yaitu sebanyak responden $48,6 \%$, wiraswasta $28,6 \%$.

\section{Hubungan tingkat stres dengan perawatan diri}

Tabel 2. Hubungan tingkat stres dengan perawatan diri

\begin{tabular}{|c|c|c|c|c|c|}
\hline $\begin{array}{l}\text { Perawatan } \\
\text { Diri }\end{array}$ & Baik & $\%$ & $\begin{array}{l}\text { Kurang } \\
\text { Baik }\end{array}$ & $\%$ & $\begin{array}{l}\mathbf{P} \\
\text { Value }\end{array}$ \\
\hline \multicolumn{6}{|c|}{ Tingkat Stress } \\
\hline Ringan & 10 & 83,3 & 5 & 21,7 & \multirow{3}{*}{0,001} \\
\hline Berat & 2 & 15,7 & 18 & 78,3 & \\
\hline Total & 12 & 100 & 23 & 100 & \\
\hline
\end{tabular}

Berdasarkan Tabel 2 menunjukkan bahwa sebagian besar responden mengalami stres berat yaitu sebanyak 20 (57, I\%) dapat melakukan perawatan diri dengan baik hanya $2(17,7 \%)$ dan 18 $(78,3 \%)$ responden kurang baik dalam melakukan perawatan diri. Responden yang mengalami stres ringan sebanyak 15 (42,9\%) mampu melakukan perawatan diri dengan baik sebanyak 10 $(83,3 \%)$ dan 5 (21,7\%) belum mampu melakukan perawatan diri dengan baik. Pada hasil uji chi square di dapatkan nilai $p$ value $=$ 0,00 I, dimana nilai $p<\alpha(\alpha=0,05)$ maka terdapat hubungan yang bermakna antara tingkat stres dengan perawatan diri, dimana responden yang mengalami stres berat memiliki perawatan diri yang rendah dibandingkan dengan responden yang mengalami stres ringan dan responden yang mengalami stres berat I,8 kali lebih beresiko tidak melakukan perawatan diri dengan baik.

Stres adalah keadaan internal yang dapat diakibatkan oleh tuntunan fisik dari tubuh (kondisi penyakit, latihan,dll) atau oleh kondisi lingkungan dan sosial yang dinilai potensial membahayakan, tidak terkendali atau melebihi kemampuan individu untuk melakukan koping. stres pada penderita Diabetes Mellitus dapat berakibat ketidakmampuan dalam pengontrolan kadar gula darah. Pada keadaan stres akan terjadi peningkatan hormon katekolamin, glukagon, glukokortikoid, endrotopin dan hormon pertumbuhan. 
Selanjutnya kortisol juga akan berdampak terhadap penurunan daya tahan tubuh penderita DM tipe 2 , sehingga akan mudah untuk mengalami permasalahan kesehatan. Dampak yang terjadi baik fisik maupun psikologis tentunya akan berlanjut terhadap penurunan kemampuan dalam melakukan perawatan diri sendiri. Stres berhubungan dengan penurunan kemampuan individu dalam melakukan perawatan dirinya. Klien yang mengalami stres, memiliki motivasi dan manajemen diri yang rendah sehingga kemampuan dalam mengontrol gula darah kurang ( $\mathrm{Wu}, 20 \mathrm{II}$ dalam kusniawati 20 I I). Masalah emosional diketahui mempunyai hubungan yang signifikan terhadap perilaku perawatan diri. Hal ini dikarenakan masalah yang dialami klien diabetes melitus akan mengakibatkan klien tidak memiliki semangat dalam program terapi yang dialami. Stres pada klien diabetes melitus dapat menimbulkan pesimisme dan menurunkan self-efficacy sehingga mengakibatkan kepatuhan perawatan diri berkurang, beban gejala yang lebih tinggi, kontrol glikemik yang rendah dan resiko komplikasi diabetes yang tinggi. Hal inilah yang dapat menjadi masalah psikososial yang dapat mengganggu perawatan kesehatan sehari-hari pada penderita diabetes (Khuzaimah et al., 2015 dalam Sari WP, 2016). Penelitian ini sejalan dengan penelitian E.PPutra (2016) menyatakan adanya hubungan antara diabetes distress dengan perilaku perawatan diri pada penyandang DM tipe 2 dengan tingkat keeratan kuat yang berarti semakin tinggi diabetes distres semakin rendah perilaku perawatan dirinya. Hasil penelitian Eplriska (2016) di RSUD Pirngadi Medan dengan jumlah sampel 80 responden menunjukan adanya pengaruh stres terhadap terjadinya komplikasi ulkus kaki diabetes dan analisa multivariat menunjukan bahwa stres merupakan variabel yang paling mempengaruhi terjadinya komplikasi tersebut. Diabetes Mellitus dapat berakibat ketidakmampuan dalam pengontrolan kadar gula darah. Pada keadaan stres akan terjadi peningkatan hormone katekolamin, glukagon, glukokortikoid, Bendrotopin dan hormon pertumbuhan. Selanjutnya kortisol juga akan berdampak terhadap penurunan daya tahan tubuh penderita DM tipe 2, sehingga akan mudah untuk mengalami permasalahan kesehatan. Dampak yang terjadi baik fisik maupun psikologis tentunya akan berlanjut terhadap penurunan kemampuan dalam melakukan perawatan diri sendiri, namun penelitian ini tidak sejalan dengan Saputri ririn (2010) menyatakan bahwa Stress pada pasien DM sebagian besar normalyaitu 22 responden (56\%), Perilaku pasien DM dalam mengontrol gula darah sebagian besar positif yaitu 21 responden (54\%) dan tidak ada hubungan antara stress dengan perilaku pasien DM dalam mengontrol gula darah, perilaku pasien DM dalam mengontrol gula darah tidak hanya dipengaruhi oleh tingkat stress tetapi ada banyak faktor lain yang berkontribusi diantaranya adalah self efficasy (keyakinan diri) dan motivasi.

\section{KESIMPULAN}

I. Karakteristik Responden pada penelitian ini diketahui bahwa mayoritas responden berjenis kelamin perempuan dan berusia $>45$ tahun, sebagian besar responden tingkat pendidikan SMA, Pekerjaan kebanyakan adalah tidak bekerja dan wiraswasta/berdagang, dan lama menderita DM lebih banyak pada rentang I-5 tahun.

2 Hasil penelitian ini menunjukan tingkat stres responden di poli penyakit dalam lebih banyak mengalami stres berat.

3. Pada penelitian ini diketahui bahwa sebagian besar responden belum melakukan perawatan diri (self care) secara maksimal.

4. Berdasarkan hasil penelitian ini diketahui bahwa terdapat hubungan antara tingkat stres dengan perawatan diri klien DM Tipe 2, dimana semakin tinggi tingkat stres maka semakin rendah perilaku perawatan dirinya.

\section{UCAPAN TERIMA KASIH}

Berisi Informasi ucapan terima kasih serta penghargaan kepada pihak-pihak yang telah berpartisipasi dalam kegiatan penelitian yang dilakukan. Bisa kepada institusi penyedia anggaran maupun hibah (mencantumkan sumber dan skema hibah yang digunakan), pihak institusi tempat kegiatan penelitian dilakukan, narasumber, organisasi dan unsur masyarakat, serta sivitas akademika yang telah membantu pelaksanaan kegiatan penelitian.

\section{REFERENSI}

I. Kemenkes RI. 2014. Pusat data dan informasi kesehatan RI.. Penyakit tidak menular. Di unduh dari http://www.pusdatin.kemkes.go.id / article /view/ I3010200029 /penyakit-tidak-menular.html pada tanggal 7 Desember 2017 
2. World Health Organization. 2016. Global Report on Diabetes. Di unduh dari http:// apps.who.int / iris/ bitstream / 10 665/20487 I/ I/978924I565257 _eng. pdf?ua=I pada tanggal 7 Desember 2017.

3. Internasional Diabetes Federation. 2017. IDF Diabetes Atlas. (online) https:// www. idf.org/ elibrary/epidemiology- research/diabetes-atlas.html di akses pada tanggal 24 November 2017.

4. Riskesdas. 2013. di unduh dari http://labmandat.litbang.depkes. go.id /images /download/laporan/RKD/2013/laporan_riskesdas_ 2013_final.pdf pada tanggal 7 Desember 2017.

5. Badan Pusat Statistik. 2016. Jumlah 10 penyakit terbanyak di provinsi kalimantan tengah. (online) https://kalteng.bps.go.id di askes pada tanggal 24 November 2017.

6. Badan Pusat Statistik. 20I5. Penyakit terbanyak di instalasi rawat jalan RSUD dr. Doris Sylvanus. (online) https://kalteng.bps.go.id di askes pada tanggal 24 November 2017.

7. Abolghasemi,S. Dan Mahmoudi G. 2012. The Effectiveness Of Stress Immunization Teaching On Stressful Psychological Feelings And Blood Glucose Control In Patients With Type 2 Diabetes. World Applied Sciences Journal 17 (3): $284-29$ di unduh dari https://pdfs.semanticscholar.org

8. Nurrokhmah. 2014. Efektivitas Pelatihan Relaksasi Untuk Menurunkan Stres Penderita Diabetes Mellitus Tipe 2. (online) http://eprints.ums.ac.id/ 39015/2 NASKAH PUBLIKASI. di akses pada tanggal 27 Desember 2017.

9. Loriza S Yan, R Marisdayana, R Irma. 2017. Hubungan penerimaan diri dan tingkat stres pada penderita diabetes mellitus.. Jurnal Endurance 2 (3), 312-322, 20I7. 10, 2017.

10. Aliaputri. 2014. Gambaran Tingkat Stres Pada Pasien DM Tipe 2 DiRuang Rawat Inap RSUD Raden Mattaher. (online) https://www.doc/245775004/ Gambaran-stres-pada-Pasien-DM- Tipe-II di askes 28 Desember 2017
II. Gillani, S. 20/2. Pharmacist intervention in home care program for diabetes patients. Journal of diabetes melitus, Volume 2 (3).

12. Kusniwati. 201I. Analisis Faktor-faktor yang berkontribusi terhadap self care diabetes pada klien diabetes melitus tipe 2 di rumah sakit umum tangggerang Universitas Indonesia : Jakarta

13. Sari Wulan Purnama. 2016. Diabetes Mellitus: Hubungan Antara Pengetahuan Sensoris, Kesadaran Diri, Tindakan Perawatan Diri Dan Kualitas

14. Eka Prima Putra. 2016. Gambaran dukungan keluarga pada pasien diabetes mellitus tipe ii diwilayah kerja puskesmas nanggalo padang tahun 2016. Diploma thesis, universitas andalas.

I5. Saputri, R. 2020. Komplikasi Sistemik Pada Pasien Diabetes Melitus Tipe 2. Jurnal IImiah Kesehatan Sandi Husada, II(I), 230-236. https://doi.org/ 0.358 |6/jiskh.v I lil.254 